\title{
An Evaluation of the Resilient Modulus and Permanent Deformation of Unbound Mixtures of Granular Materials and Rubber Particles from Scrap Tyres to Be Used in Subballast Layers
}

\author{
Carlos Hidalgo Signes a, , Pablo Martínez Fernández b , Julio Garzón-Roca a , \\ María Elvira Garrido de la Torre ${ }^{a}$, Ricardo Insa Franco ${ }^{b}$ \\ a Department of Geological and Geotechnical Engineering. Universitat Politècnica de València.. Camino de Vera, s/n, 46022, Valencia, Spain. \\ $b$ Department of Transport Engineering and Infrastructure. Universitat Politècnica de València. Camino de Vera, s/n, 46022, Valencia, Spain.
}

\begin{abstract}
Over the last years rubber from scrap tyres has been reused in different civil works such as road embankments and railway platforms due to its resilient properties, low degradation and vibration attenuation. Unfortunately, this issue is still scarce. For instance, in Spain about 175.000 tonnes of scrap tyres were collected in 2014, of which only $0.6 \%$ were reused in civil works. Aiming to contribute to the reutilisation of large quantities of this waste material, this paper focuses on the analysis of unbound mixtures of granular materials with different percentages of rubber particles to be used as subballast layers. Mixtures are tested under cyclic triaxial tests so as to obtain their resilient modulus and evaluate their permanent deformations. It is found that as the rubber content increases, the resilient modulus decreases and the permanent deformation increases. Taking into account the usual loads transmitted to the subballast layer, the optimum rubber content that does not compromise the behaviour of the mixture is set in a range between $2.5 \%$ and $5 \%$ in terms of weight.
\end{abstract}

\section{Introduction}

Scrap tyres are a dangerous waste material. In Europe about 3 million tonnes are discarded every year, hence they are a significant environmental problem. In Spain, scrap tyres are managed by SIGNUS, which deals with 300,000 
CIT2016 - XII Congreso de Ingeniería del Transporte València, Universitat Politècnica de València, 2016. DOI: http://dx.doi.org/10.4995/CIT2016.2016.4231

tonnes every year, although this quantity is decreasing due to the current economic crisis that started in 2007. In order to deal with the large stock of scrap tyres in Spain, the government approved the National Scrap Tyres Plan 20072015 , which aims to reuse at least $20 \%$ of scrap tyres in earthworks. However, according to SIGNUS, in 2014 only $0.6 \%$ of the total amount of scrap tyres was used in road construction, and almost none in railways.

In order to encourage the reutilisation of scrap tyres as part of railway platforms, a research to assess the viability of mixing rubber particles with traditional aggregates in subballast layers was carried out. As a first step, the effect of such addition on resistance to fragmentation and degradation was studied, as well as the bearing capacity and the permeability. The optimum rubber content that ensure the fulfilment of all the requirements set by the General Technical Specifications for Railway Materials PF-7: Subballast (Spanish Ministry of Public Works, 2006) was then obtained. This paper represents a further step, being now the objective to analyse the stress-strain behaviour of rubberaggregate mixtures under cyclic loads.

More specifically, the objective of this paper is to study the evolution of the Resilient Modulus $\left(\mathrm{M}_{\mathrm{r}}\right)$ with regards to the rubber content and to assess the stress level that causes excessive permanent deformations and how it varies with each rubber percentage. In order to do so, mixtures with varying percentages of rubber were prepared $(1,2.5$ and $5 \%$ in terms of weight) and were tested by means of cyclic load triaxial tests.

\section{Materials and Methods}

\subsection{Material selection and sampling}

To assess the properties of rubber-aggregate mixtures, different representative materials were sampled. Aggregates were of calcareous nature, a lithology very typical of South-Eastern Spain, and were sampled from a quarry located in the North of Alicante, specialised in subballast materials. The aggregates had a maximum size of $20 \mathrm{~mm}$ and fulfilled all the requirements set by the General Technical Specifications for Railway Materials PF-7: Subballast (Spanish Ministry of Public Works, 2006).

Rubber particles were provided by a company specialised in the treatment and grinding of scrap tyres. Three different particle sizes were chosen, namely 20,2 and $1 \mathrm{~mm}$, all free of metallic wires, in order to ensure a proper size gradation of the mixtures. Figure 1 shows the sampled materials. Sampling was carried out according to ASTM D75/D75M and ASTM C702-98.
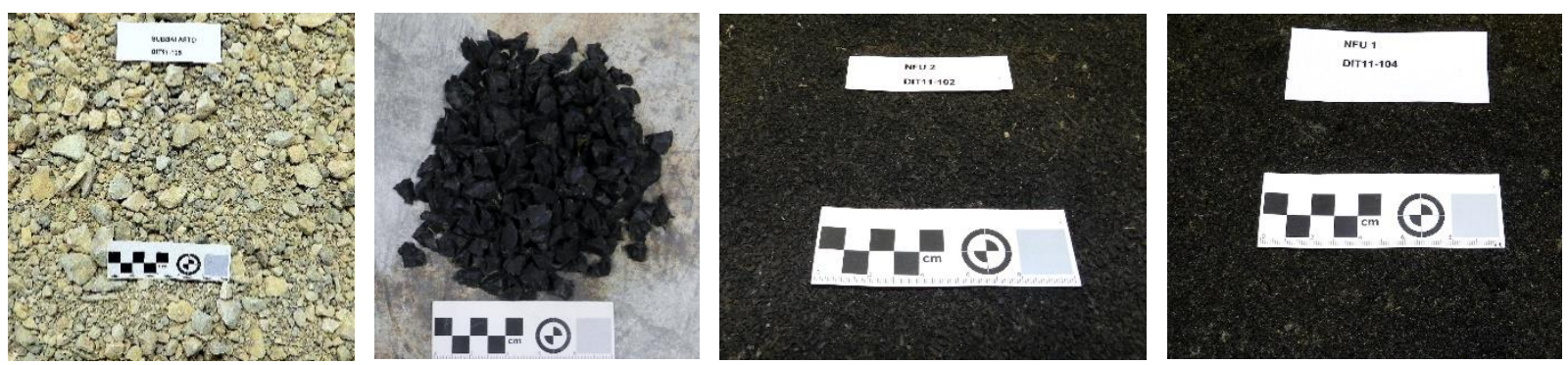

Figure 1. Subballast and rubber samples. (a) Unbound Granular Material-Subballast (b) Rubber 20 mm. (c) Rubber 2 mm. (d) Rubber 1 mm.

\subsection{Mixture reparation. Compaction Test}

The testing campaign devised for this paper focused on cyclic load triaxial tests aiming to obtain the resilient parameters of the mixtures as well as to study their permanent deformation. In order to carry out these tests, mixtures of aggregates and rubber particles were prepared with varying percentages of the latter, i.e. $1 \%, 2.5 \%$ and $5 \%$ in terms of weight. Before the cyclic tests, a Proctor Modified compaction test was carried out to all the mixtures as well as the unmixed aggregate, according to ASTM D1557 (Energy $2700 \mathrm{kN}-\mathrm{m} / \mathrm{m}^{3}$; blows/layer 56 , hammer mass weight $4.535 \mathrm{~kg}$; fall height $457 \mathrm{~mm}$ ), hence obtaining the maximum dry density and optimum compaction moisture. All mixtures were prepared by means of a planetary mixer. First of all the dried aggregate was placed in the mixer, secondly the rubber particles were added and the combination was stirred until and homogeneous mixture was 
CIT2016 - XII Congreso de Ingeniería del Transporte València, Universitat Politècnica de València, 2016. DOI: http://dx.doi.org/10.4995/CIT2016.2016.4231

achieved. Afterwards the corresponding amount of water was added and a second process of stirring was performed for two more minutes. The final mixture was placed in an isolated container and left to rest in a humid chamber for two hours. Both this preparation process and all tests referred in this paper were carried out in the Geotechnical Laboratory and the Roads Laboratory of Universitat Politècnica de València.

\subsection{Resilient Modulus Test}

The cyclic load triaxial test is usually used to design flexible pavements (Tutumluer and Seyhan, 1999). The objective of this test is to obtain the resilient modulus $\left(\mathrm{M}_{\mathrm{r}}\right)$ which provides insight on the elastic properties of the materials used under roads and railways. Aggregates, once compacted to their maximum dry density, experience permanent deformations when submitted to cyclic loads which tend to increase their density. Once the material is post-compacted, all further deformations are recoverable and thus the material behaves as a purely elastic one. The resilient modulus is obtained from the cyclic load triaxial test where, given a constant confining pressure, $\mathrm{M}_{\mathrm{r}}$ is calculated from the relationship between the axial deviator stress $\sigma_{\mathrm{d}}$ and the recoverable axial strain $\varepsilon_{\mathrm{r}}$ (Sedd et al., 1995; Garnica et al., 2001).

In order to obtain these parameters the test were carried out according to AASHTO T 307-99 (2003). Four cylindrical specimens (diameter $100 \mathrm{~mm}$ and height $200 \mathrm{~mm}$ ) were prepared for each of the mixtures as well as for the pattern aggregate, in all cases with a maximum particle size of $20 \mathrm{~mm}$ and optimum moisture content. All specimens were compacted by means of dynamic compaction with Proctor Modified energy (i.e. a mass of $2.5 \mathrm{~kg}$ falling 100 times from a height of $305 \mathrm{~mm}$ ). After compaction, all specimens were protected with a rubber membrane so as to keep the moisture level until testing. Both sides of each cylinder were covered with porous discs of asphalt concrete in order to better handle the specimens (these discs were removed before testing). The test was performed using a triaxial cell where the confining stress was applied through compressed air and the cyclic loads by means of a $14 \mathrm{KN}$ Servo-Pneumatic Universal Testing Machine (Model Cooper Technology NU-14) at a controlled temperature of $25^{\circ} \mathrm{C}$. Stresses during the test were measured through an Internal Load Cell while strains were measured using two LVDT (Figure 2).
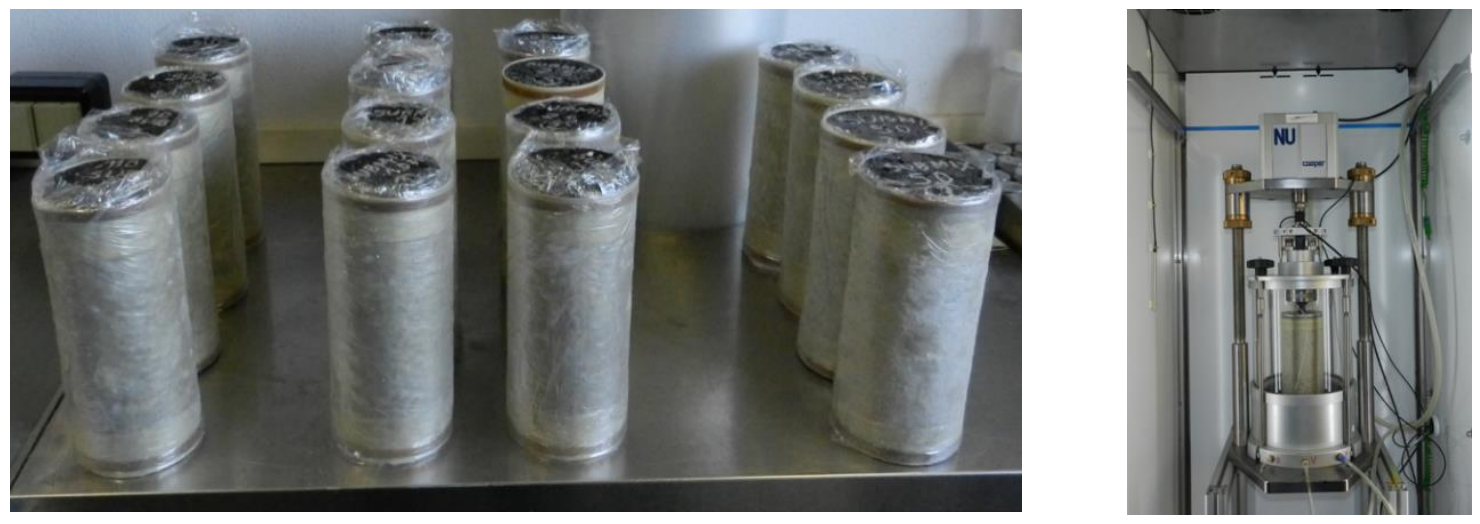

Figure 2. (a) Cylindrical Specimens $\varnothing 100$ mm H 200 mm (b) Cyclic Load Triaxial Test.

To obtain the resilient modulus $\left(\mathrm{M}_{\mathrm{r}}\right)$, a conditioning pressure was applied to each specimen during 500 cycles with a confining stress $\left(\sigma_{3}\right)$ and a deviator stress $\left(\sigma_{\text {cyclic }}\right)$ of $103.4 \mathrm{kPa}$, which equals to a cyclic axial stress of $93.1 \mathrm{kPa}$ with a $1 \mathrm{~Hz}$ Haversine-shape load pulse. Afterwards a series of cyclic loads were applied with varying combinations of confining stress and deviator stress (Table 1).

Table 1. Testing Sequences for Base/Subbase Materials. AASHTO T 307-99 (2003).

\begin{tabular}{|c|c|c|c|c|c|}
\hline & Confining & Max. Axial & Cyclic Stress & Constant Stress & Load \\
\hline Sequence & Pressure, $\sigma_{3}$ & Stress, $\sigma_{\max }$ & $\sigma_{\text {cyclic }}$ & $0.1 \sigma_{1 \max }$ & Applications \\
\hline
\end{tabular}




\begin{tabular}{cccccc} 
No. & $\mathrm{kPa}$ & $\mathrm{kPa}$ & $\mathrm{kPa}$ & $\mathrm{kPa}$ & No. \\
\hline 0 & 103.4 & 103.4 & 93.1 & 10.3 & $500-1000$ \\
1 & 20.7 & 20.7 & 18.6 & 2.1 & 100 \\
2 & 20.7 & 41.4 & 37.3 & 4.1 & 100 \\
3 & 20.7 & 62.1 & 55.9 & 6.2 & 100 \\
4 & 34.5 & 34.5 & 31.0 & 3.5 & 100 \\
5 & 34.5 & 68.9 & 62.0 & 6.9 & 100 \\
6 & 34.5 & 103.4 & 93.1 & 10.3 & 100 \\
7 & 68.9 & 68.9 & 62.0 & 6.9 & 100 \\
8 & 68.9 & 137.9 & 124.1 & 13.8 & 100 \\
9 & 68.9 & 206.8 & 186.1 & 20.7 & 100 \\
10 & 103.4 & 68.9 & 62.0 & 6.9 & 100 \\
11 & 103.4 & 103.4 & 93.1 & 10.3 & 100 \\
12 & 103.4 & 206.8 & 186.1 & 20.7 & 100 \\
13 & 137.9 & 103.4 & 93.1 & 10.3 & 100 \\
14 & 137.9 & 137.9 & 124.1 & 13.8 & 100 \\
15 & 137.9 & 275.8 & 248.2 & 27.6 & 100 \\
\hline
\end{tabular}

The average deviator stress from the last five cycles and the recovered axial deformation $\left(\varepsilon_{\mathrm{r}}\right)$ were used to obtain the resilient modulus $\mathrm{M}_{\mathrm{r}}$ from both the pattern and the mixtures. Additionally the evolution of the permanent axial deformation $\left(\varepsilon_{\mathrm{p}}\right)$ was also measured. Once the triaxial test was done, the final moisture content of each specimen was measured.

\subsection{Permanent Deformation Test}

The addition of rubber not only may affect the elastic properties of the subballast layer, but it is also important to evaluate its impact in the structural behaviour of said layer in terms of permanent deformation. According to the "Shakedown" theory (Werkmeister, 2011), when an aggregate experiences low level cyclic loads, permanent deformations tend to stabilise after a number of cycles. However, if the applied loads are high enough, permanent deformations rapidly increase even to the point of a gradual failure. Therefore, there is a limit of critical stress that marks the boundary between stable and unstable situations. This is the Plastic Creep Limit, and if the loads applied are below such limit, the deformations experienced by the material will fall within acceptable limits and failure will only take place after a large number of loading cycles (Cerni, 2012).

In order to obtain the Plastic Creep Limit (PCL), the methodology found in UNE EN 13286-7 was followed. Permanent Deformation Tests are carried out on a specimen with four different confining stresses, namely 20, 50, 70 and $100 \mathrm{kPa}$. The test starts by applying the lower deviator stress shown in Table 2 (the axial cyclic load is a $7 \mathrm{~Hz}$ senoid) and then increasing it sequentially until reaching failure. The PCL is then calculated by obtaining the stress combination $\left(\sigma_{1}, \sigma_{3}\right)$ corresponding to the situation where the difference in the permanent deformation between the load cycles 3000 and 5000 is higher than 400 microstrain units $\left(\Delta \varepsilon_{\mathrm{p}}=\varepsilon_{\mathrm{p} 5000}-\varepsilon_{\mathrm{p} 3000}>400 \mu\right.$ strain $)$.

Afterwards, the axial stress $\sigma_{1}$ is plotted against the $\sigma_{1} / \sigma_{3}$ ratio for all the specimens tested of each mixture type. The curve thus obtained fits the following equation (1):

$\sigma_{1}=\alpha\left(\frac{\sigma_{1}}{\sigma_{3}}\right)^{\beta}$

Where $\sigma_{1}$ is the axial stress $(\mathrm{kPa}), \sigma_{3}$ is the confining pressure $(\mathrm{kPa})$, and $\alpha(\mathrm{kPa})$ and $\beta$ are coefficients depending on material/mixtures. By obtaining this envelope the deformation behaviour of the mixtures can be predicted for each combination of stress.

Table 2: Stress levels during the multi-stage cyclic triaxial test. UNE EN 13286-7 Annex C

$\begin{array}{ccc}\text { Confining } & \text { Minimum } & \text { Stress Ratio } \sigma_{\mathrm{d}} / \sigma_{3} \\ \text { Stress } \sigma_{3} & \text { Deviator } & \end{array}$


CIT2016 - XII Congreso de Ingeniería del Transporte València, Universitat Politècnica de València, 2016. DOI: http://dx.doi.org/10.4995/CIT2016.2016.4231

\begin{tabular}{|c|c|c|c|c|c|}
\hline $\mathbf{k P a}$ & $\begin{array}{c}\text { Stress } \sigma_{\mathrm{d}} \\
\mathbf{k P a} \\
\end{array}$ & Subballast & Mix 1.0 & Mix 2.5 & Mix 5.0 \\
\hline 20 & 5 & $\begin{array}{l}1 ; 2 ; 3 ; 4 ; 5 ; 6 ; 7 ; 8 ; 9 ; 10 ; 11 \\
12 ; 13 ; 14 ; 15 ; 16 ; 17 ; 18 ; 19 \\
20 ; 21\end{array}$ & $\begin{array}{l}1 ; 2 ; 3 ; 4 ; 5 ; 6 ; 7 ; 8 \\
9 ; 10 ; 11\end{array}$ & $\begin{array}{l}1 ; 2 ; 3 ; 4 ; 5 ; 6 ; 7 ; \\
8\end{array}$ & $1 ; 2 ; 3 ; 4 ; 5 ; 6$ \\
\hline 50 & 5 & $\begin{array}{l}1 ; 1.5 ; 2 ; 2.5 ; 3 ; 4 ; 5 ; 6 ; 7 ; 8 ; 9 ; \\
10 ; 11 ; 12 ; 13 ; 14 ; 15 ; 16 ; 17 ; 18\end{array}$ & $\begin{array}{l}1 ; 1.5 ; 2 ; 2.5 ; 3 ; 4 ; 5 \\
6 ; 7 ; 8 ; 9\end{array}$ & $\begin{array}{l}1 ; 1.5 ; 2 ; 2.5 ; 3 ; 4 \\
5 ; 6 ; 7\end{array}$ & $1 ; 1.5 ; 2 ; 2.5 ; 3 ; 4$ \\
\hline 70 & 5 & $\begin{array}{l}1 ; 1.5 ; 2 ; 2.5 ; 3 ; 4 ; 5 ; 6 ; 7 ; 8 ; 9 ; \\
10\end{array}$ & $\begin{array}{l}1 ; 1.5 ; 2 ; 2.5 ; 3 ; 4 ; 5 \\
6 ; 7 ; 8 ; 9\end{array}$ & $\begin{array}{l}1 ; 1.5 ; 2 ; 2.5 ; 3 ; 4 \\
5 ; 6\end{array}$ & $1 ; 1.5 ; 2 ; 2.5 ; 3 ; 4$ \\
\hline 150 & 5 & $1 ; 1.5 ; 2 ; 2.5 ; 3 ; 4 ; 5 ; 6 ; 7 ; 8 ; 9$ & $\begin{array}{l}1 ; 1.5 ; 2 ; 2.5 ; 3 ; 4 ; 5 ; \\
6 ; 7\end{array}$ & $\begin{array}{l}1 ; 1.5 ; 2 ; 2.5 ; 3 ; 4 ; \\
5 ; 6\end{array}$ & $1 ; 1.5 ; 2 ; 2.5 ; 3 ; 4$ \\
\hline
\end{tabular}

These tests have been performed using the same equipment aforementioned. For each of the mixtures studied four cylindrical specimens have been made, each one with a diameter of $100 \mathrm{~mm}$ and $200 \mathrm{~mm}$ of height and compacted at $100 \%$ Modified Proctor with optimum moisture content. All specimens were protected after compaction by means of a $0.6 \mathrm{~mm}$ thick latex membrane. All tests were performed with double drainage during the application of the stress combination.

\section{Results and Discussion}

\subsection{Characterisation Tests}

The granular material is a well-graded gravel with silt (GW-GM) less than $10 \%$ of fine content, non-plastic nature, and a Sand Equivalent (SE) of 47\%. Resistance to fragmentation (LA) and abrasion (MDH) are very low, 25 and 11 respectively.

Regarding the rubber particles, their Specific Gravity is $1.136 \mathrm{~g} / \mathrm{cm}^{3}, 2.5$ times lighter than the unbound granular material, while their absorption is $5.0 \%$, much higher than the aggregate. For further details regarding the characterisation of the unmixed materials see Hidalgo et al. (2015).

\subsection{Resilient Modulus}

Table 3 shows that the resilient modulus $\left(\mathrm{M}_{\mathrm{r}}\right)$ decreases with the addition of rubber. This was expected as density is reduced when rubber is added and that directly affects the resilient modulus. The modulus used for this comparison corresponds to a confining pressure of $34.5 \mathrm{kPa}$ and a deviator stress of $103.4 \mathrm{kPa}$ [31] (National Cooperative Highway Research Program, 2004). It is usually required, for materials to be used as support layers, that the resilient modulus is at least over $100 \mathrm{MPa}$ (Brown and Pappin, 1985), therefore the addition of rubber should be limited to less than 5 $\%$ in weight. However, the resilient modulus depends on the level of stress, and this is taken into account in Fig. 3, where $\mathrm{M}_{\mathrm{r}}$ is compared with $\Theta$, which is the sum of principal stresses (2):

$$
\Theta=\sigma_{1}+2 \sigma_{3}
$$

Table 3: Results from the cyclic load triaxial test.

\begin{tabular}{lcccc}
\cline { 2 - 4 } Parameter & Subballast & Mix 1.0\% & Mix 2.5\% & Mix 5.0\% \\
\hline Dry Unit Weight, $\gamma_{\mathrm{d}}\left(\mathrm{g} / \mathrm{cm}^{3}\right)$ & 2.32 & 2.30 & 2.25 & 2.17 \\
Resilient Modulus, $\mathrm{Mr}(\mathrm{MPa})$ & 249.6 & 192.3 & 167.4 & 92.8 \\
Permanent Strain, $\varepsilon_{\mathrm{p}}(\%)$ & 0.233 & 0.275 & 0.400 & 0.750
\end{tabular}




\begin{tabular}{lcccc} 
Resilient Strain, $\varepsilon_{\mathrm{r}}(\%)$ & 0.042 & 0.051 & 0.057 & 0.103 \\
Initial Moisture content, $\mathrm{W}_{\mathrm{o}}(\%)$ & 6.2 & 6.2 & 6.2 & 6.2 \\
Final Moisture content, $\mathrm{W}_{\mathrm{f}}(\%)$ & 4.8 & 4.5 & 5.1 & 5.1 \\
\hline
\end{tabular}

The trend lines drawn for each mix as well as for the subballast correspond to the nonlinear Bulk Stress Model usually used (Araya et. al, 2012) to study the resilient deformation of unbound granular materials such as the ones considered in this study. This model is ruled by the following Eq. (3):

$M_{r}=K_{1} \Theta^{K_{2}}$

Where $K_{l}$ and $K_{2}$ are non-linear parameters which depend on the material studied.

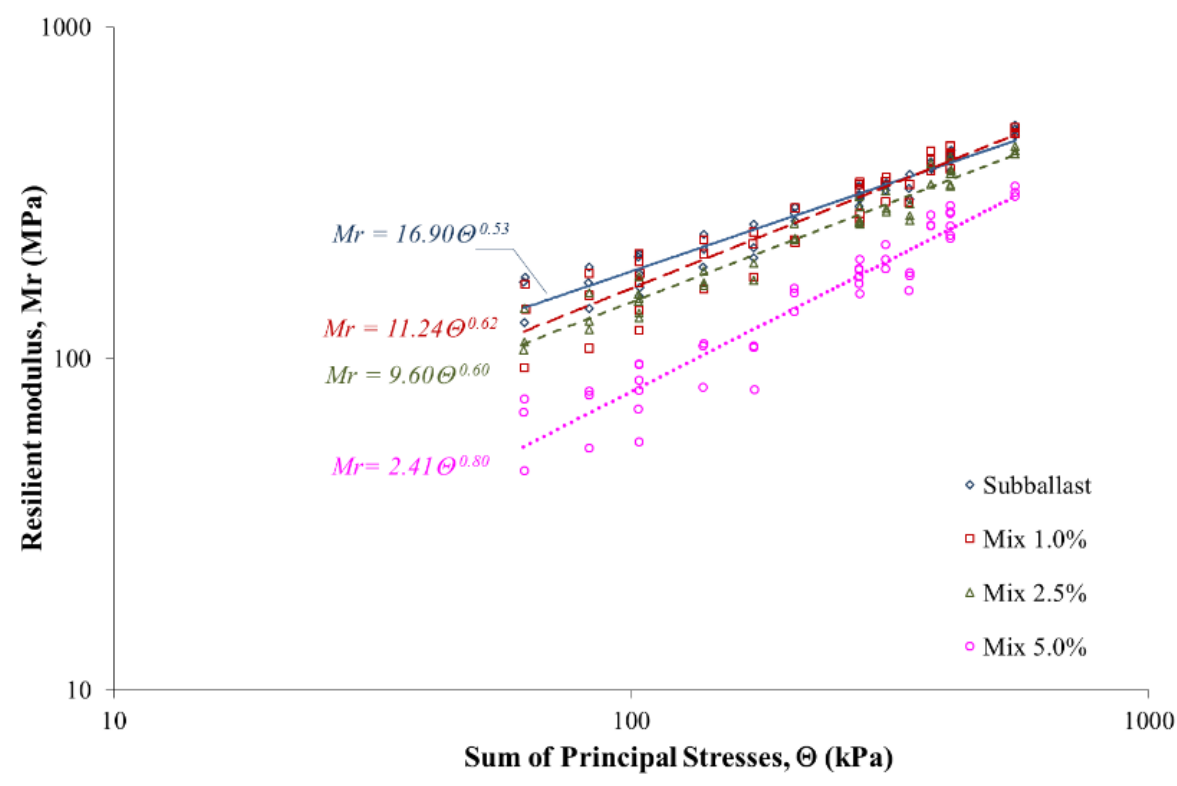

Figure 3. Resilient Modulus vs. Sum of Principal Stresses

From Figure 3 it is clear that, at lower stress levels, the difference in the resilient modulus due to the addition of rubber is much higher than that found and higher stress levels. However, it is worth nothing that for all samples the resilient modulus increases with the stress level; hence the addition of rubber does not alter the typical behaviour of an unbound granular material (Gudishala, 2004).

All mixtures except MIX 5.0 yield $K_{I}$ and $K_{2}$ parameters similar to those of an unmixed aggregated according to several previous studies (Rada and Witczak, 1981; Araya et al., 2011; Fortunato et al., 2012).

\subsection{Permanent Deformation}

Table 4 shows the average results obtained during the permanent deformation test for the four specimens of each mixture studied.

Table 4: Dry unit weight and moisture content before and after Permanent Deformation Test.

\begin{tabular}{lcccc}
\cline { 2 - 5 } & Subballast & Mix 1.0 & Mix 2.5 & Mix 5.0 \\
\hline Max. Dry Unit Weight, $\gamma_{\mathrm{d}}{ }^{\mathrm{PM}}\left(\mathrm{g} / \mathrm{cm}^{3}\right)$ & 2.35 & 2.28 & 2.24 & 2.18
\end{tabular}


As that figure shows, the addition of rubber modifies the Plastic Creep Limit so that the mixtures with higher rubber content experience plastic creep with lower $\sigma_{1} / \sigma_{3}$ stress levels. The usual stress levels in subballast layers under railway tracks are below $100 \mathrm{kPa}$ (Peña, 2003), with a $\sigma_{1} / \sigma_{3}$ ratio between 3 and 4 (as indicated by the red box in Figure 4). Taking into account these levels and the results shown in Figure 4, it is clear that the addition of rubber over 5\% (in terms of weight) is undesirable as the resultant mixture may experience a combination of stress over the PCL, and thus the subballast layer will be more prone to failure under repeated loading.

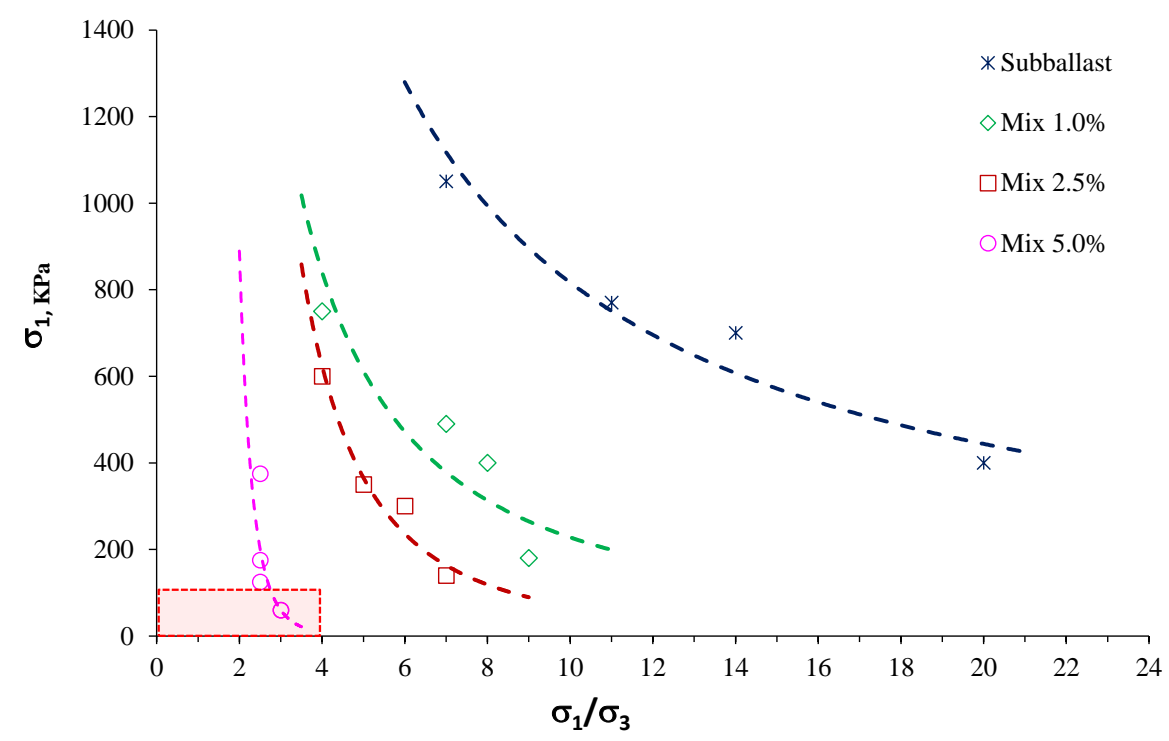

Figure 4 Plastic Creep Limits (PCL) for each mixture. The red box marks the usual stress values in a subballast layer.

Non-cohesive materials may be classified through their permanent deformability (UNE 13286-7:2008, Annex C.4). As shown in Figure 5(a), taking into account a common stress combination in the subballast layer, permanent deformation presents three different behaviours depending on the rubber content. The pattern material as well as the Mix 1.0\% shows stable deformation behaviour - Range A: plastic accommodation. Mix $2.5 \%$ experiences plastic creep after a high number of load cycles - Range B: plastic creep. Finally, the Mix 5.0\% reaches failure after a low number of load cycles - Range C: Progressive plastic collapse.

Figure 5(b) shows the maximum permanent deformation experienced by each mixture for a stress combination of $50 \mathrm{kPa}\left(\sigma_{3}\right)$ and $100 \mathrm{kPa}\left(\sigma_{\mathrm{d}}\right)$. Adding rubber particles to the aggregate increases the mixture's permanent deformation due to the lower stiffness of rubber. The trend is approximately linear and may be defined by the following equation (4):

permanent deformation $=a \cdot$ rubber $+b$

Where both the permanent deformation and the rubber content are in percentages (the latter with regards to the mixture total weight) and $a$ and $b$ are the equation parameters. As figure 5(b) shows, the values of $a$ and $b$ are 0.346 and 0.239 , respectively, with a correlation coefficient $\left(\mathrm{R}^{2}\right)$ higher than $90 \%$. 

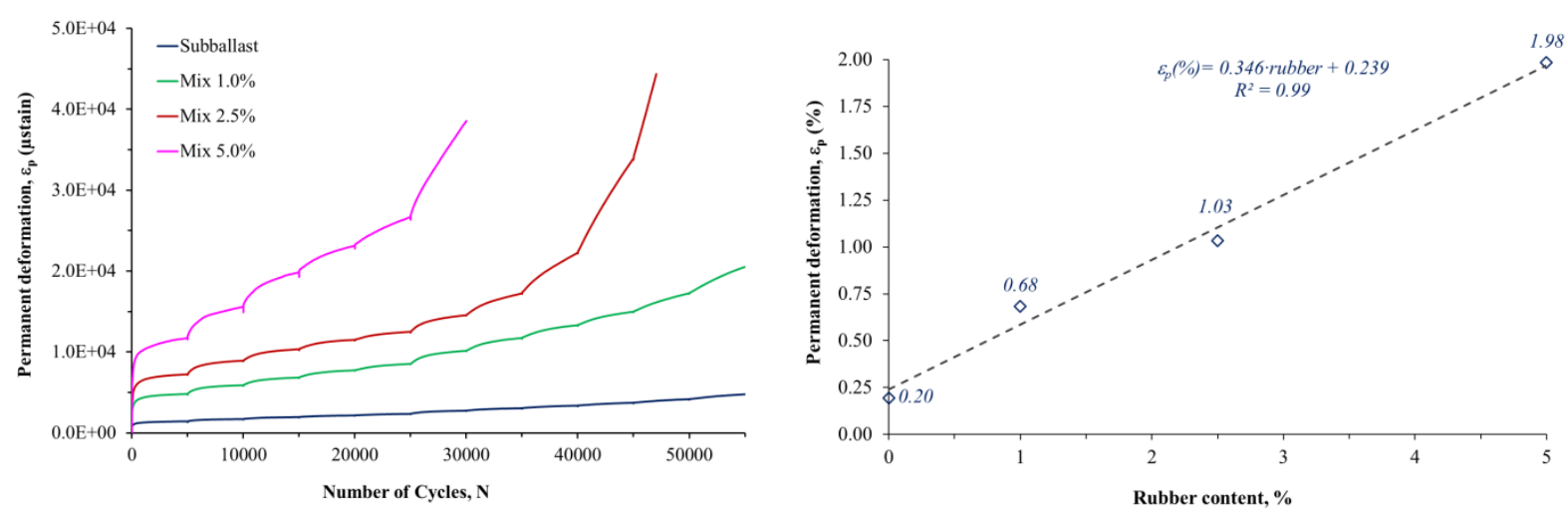

Fig.5 (a) Permanent deformation vs. Number of Cycles with confining pressure $\sigma_{3} 50 \mathrm{kPa}$. (b) Permanent deformation vs. Rubber content with stress level $\sigma_{3} 50 \mathrm{kPa}$ and $\sigma_{\mathrm{d}} 100 \mathrm{kPa}$.

\subsection{Optimum Rubber Content}

Considering all the results obtained from the cyclic triaxial tests, and taking into account the usual stress levels measured in subballast layers, which are below $100 \mathrm{kPa}$ (Peña, 2003), the percentage of rubber should be kept below $5 \%$ in terms of weight to avoid plastic creep and instability. This result is consistent with the optimum content obtained during previous stages of research (Hidalgo et al., 2015).

\section{Conclusions}

This paper is a continuation of a wider research project that aims to characterise rubber-aggregate mixtures and their potential use as subballast layers under railway tracks. The present paper focuses on the study of the stress-strain behaviour of such mixtures under cyclic loads. In order to assess this behaviour, several cyclic load triaxial tests were carried out for mixtures with varying percentage of rubber content.

The results obtained show that the resilient modulus $\left(\mathrm{M}_{\mathrm{r}}\right)$ tends to decrease as the rubber content increases, although all the mixtures studied except the Mix 5\% yield a $\mathrm{M}_{\mathrm{r}}$ higher than $100 \mathrm{kPa}$, which is an acceptable level for subballast layers.

Moreover, adding rubber reduces the Plastic Creep Limit of the mixture. Percentages higher than 5\% in terms of weight may lead to unstable mixtures which experience large deformations after a small number of load cycles. The Mix $5 \%$ showed a progressive plastic collapse for a stress combination of $50 \mathrm{kPa}\left(\sigma_{3}\right)$ and $100 \mathrm{kPa}\left(\sigma_{\mathrm{d}}\right)$.

All these results show that the percentage of rubber should be kept below $5 \%$ in order to obtain a mixture with enough resilient modulus and below the Plastic Creep Limit. This threshold is consistent with the one obtained during previous stages of research with regards to the bearing capacity of the mixtures.

\section{Acknowledgements}

The authors wish to thank GUEROLA for providing the soil samples from its quarry, EMRO for providing the rubber particles and Elías Medel Perallón and Lucia Barbone for their help during the laboratory tests.

\section{References}

AASHTO T 307-99, 2003, Standard method of test for determining the resilient modulus of soils and aggregate materials.

Araya, A., Huurman, M., Moleenar, A., Houben, L., 2012, Investigation of the resilient behavior of granular base materials with simple test apparatus. Materials and Structures 45, 695-705. 
ASTM C702-98, 2003, Historical Standard: Practice regulations to reduce aggregate samples to trial size.

ASTM D75/D75M, 2009, Standard practice for sampling aggregates.

ASTM D1557, 2012, Standard test methods for laboratory compaction characteristics of soil using modified effort $\left(56,000 \mathrm{ft}-\mathrm{lbf} / \mathrm{ft}^{3}(2,700 \mathrm{kN}\right.$ $\left.\mathrm{m} / \mathrm{m}^{3}\right)$ )

Brown, S.F., Pappin, J.W., 1985, Analysis of pavements with granular bases. Transportation Research Record 1022, 52-59.

Cerni, G., Cardone, F., Virgili, A., Camilli, S., 2012, Characterisation of permanent deformation behaviour of unbound granular materials under repeated triaxial loading. Construction and Building Materials 28(1), 79-87.

Fortunato, E., Paixao, A., Fontul, S., 2012, Improving the use of unbound granular materials in railway sub-ballast layer, in "Advances in Transportation Geotechnics II". Miura et al. (Ed.). Taylor \& Francis Group, London, UK.

Garnica, P.A., Pérez, G.N., Gomes, L.A., 2001, Módulo de resiliencia en suelos finos y materiales granulares (Resilient modulus in fine soils and aggregate materials). Publicación técnica 142, Secretaría de Comunicaciones y Transportes (SCI), Instituto Mexicano del Transporte (IMT).

Gudishala, R., 2004, Development of resilient modulus prediction models for base and subgrade pavement layers from in situ devices test results. $\mathrm{PhD}$ thesis, Sri Krishnadevaraya University, Anantapur, India.

Hidalgo, C., Martínez, P., Medel, E., Insa, R., 2015, Characterisation of an unbound granular mixture with waste tyre rubber for subballast layers. Materials and Structures 45(12) 3847-3861.

National Cooperative Highway Research Program, 2004, Research results digest. Laboratory determination of resilient modulus for flexible pavement design. Available at: http://onlinepubs.trb.org/onlinepubs/nchrp/nchrp_rrd_285.pdf. (Accessed 1 Apr 2014).

Peña, M., 2003. Tramos de ensayo de vía en placa en la línea del Corredor del Mediterráneo para su explotación a alta velocidad (Slab track test sites in the Mediterranean Corridor for high speed use). Revista de Obras Públicas 3431, 57-68.

Spanish Ministry of Public Works, 2006, Pliego de Prescripciones Técnicas Generales de Materiales Ferroviarios PF-7: Subbalasto (General Technical Specifications for Railway Materials PF-7: Subballast). Boletín Oficial del Estado 103, 16891-16909.

Rada, G., Witczak, M.W., 1981, Comprehensive evaluation of laboratory resilient moduli results for granular materials, in "Transportation Research Record 810”. Transportation Research Board, Washington D.C., pp. 23-33.

Sedd, H.B, Chan, C.K., Monismith, C.L., 1955, Effects of repeated loading on the strength and deformation of compacted clay. HRB Proceedings, $34,541-558$.

Tutumluer, E., Seyhan, U., 1999, Laboratory determination of anisotropic aggregate resilient moduli using a new innovative test device, $78^{\text {th }}$ Annual meeting of the transportation research board, Specialty session on determination of resilient modulus for pavement design. Washington D.C., USA.

AENOR, 2008, UNE-EN 13286-7, Unbound and hydraulic bound mixtures - Part 7: Cyclic load triaxial test for unbound mixtures.

Werkmeister, S., Dawson, A.R., Wellner F., 2005, Permanent deformation behaviour of granular materials. Road Materials and Pavement Design 6(1), 31-51. 